\title{
Synthesis, Crystal Structure, Vibrational Spectra, and Thermochemical Transformations of Tris(hydroxymethyl)aminomethane
}

\author{
R. E. Khoma ${ }^{a, b}$, V. O. Gel'mbol'dt ${ }^{c}$, O. V. Shishkin ${ }^{d, e}$, V. N. Baumer, ${ }^{d, e}$ and A. A. Ennan ${ }^{a}$ \\ ${ }^{a}$ Physicochemical Institute for Human and Environmental Protection, Education Department, \\ National Academy of Sciences of Ukraine, Odessa State University, Odessa, Ukraine \\ ${ }^{b}$ Mechnikov National University, ul. Petra Velikogo 2, Odessa, 270100 Ukraine \\ ${ }^{c}$ Odessa National Medical University \\ ${ }^{d}$ Institute of Single Crystals, National Academy of Sciences of Ukraine, pr. Lenina 60, Kharkiv, 310141 Ukraine \\ ${ }^{e}$ Karazin Kharkiv National University, Kharkiv, Ukraine
}

Received April 2, 2013

\begin{abstract}
A practically promising compound, tris(hydroxymethyl)aminomethane sulfate ((TRISH) $)_{2} \mathrm{SO}_{4}$, $\mathrm{C}_{8} \mathrm{H}_{24} \mathrm{~N}_{2} \mathrm{O}_{10} \mathrm{~S}$ ) was synthesized and studied by a set of experimental methods (elemental analysis, IR and Raman spectroscopy, mass spectrometry, thermogravimetry).
\end{abstract}

DOI: $10.1134 /$ S0036023614010069

Tris(hydroxymethyl)aminomethane $\left(\mathrm{HOCH}_{2}\right)_{3} \mathrm{CNH}_{2}$ (TRIS) is used as a ligand in the synthesis of coordination compounds and as a buffer component in biochemical research [1-3]. In addition, TRIS-based compounds are of interest because they can be used as electrooptical and non-linear optical materials [4, 5]. Salts of TRIS with a number of mineral and organic acids were synthesized and characterized, for example, hexafluorosilicate (TRISH) ${ }_{2} \mathrm{SiF}_{6}[6,7]$ however, no data on the structure or properties of the sulfate of protonated TRIS were reported. This communication discusses the conditions of synthesis, structure, spectral characteristics, and thermal transformations of the sulfate (TRISH) ${ }_{2} \mathrm{SO}_{4}$.

\section{EXPERIMENTAL}

Synthesis of tris(hydroxymethyl)aminomethane sulfate (I). A solution of TRIS $(0.05 \mathrm{~mol})$ in $10 \mathrm{~mL}$ of water was placed in a cell maintained in a thermostat, and gaseous $\mathrm{SO}_{2}$ was bubbled through the solution at $0{ }^{\circ} \mathrm{C}$ at a $50 \mathrm{~mL} / \mathrm{min}$ rate to reach $\mathrm{pH}<1.0$. The solution with the precipitate was kept in air at room temperature until water was evaporated. The isolated white crystalline product I (16.65 g, yield $97.9 \%)$ was not additionally purified.

The nitrogen, carbon, and hydrogen contents were determined using a CHN elemental analyzer and sulfur was quantified by the Schoeniger method [8]. $\mathrm{X}$-ray diffraction analysis was performed on an Oxford Diffraction diffractometer $\left(\mathrm{Mo} K_{\alpha}\right.$ radiation, graphite monochromator, Sapphire-3 CCD detector). The structures were solved and refined using the SHELX-97 program package [9]. Hydrogen atoms were revealed from difference synthesis and refined by the "riding" model. IR spectra were measured on a Spectrum BX II FT-IR System instrument (PerkinElmer) (4000-350 $\mathrm{cm}^{-1}$ range; samples as $\mathrm{KBr}$ pellets); Raman spectra were recorded on a DFS-24 spectrometer (excitation by a semiconductor laser at $532 \mathrm{~nm}$; interferential monochromator); EI mass spectra were run on an MX-1321 mass spectrometer (direct sample injection; ionizing electron voltage of $70 \mathrm{eV}$ ). The thermogravimetric experiments were performed on an OD-102 Paulik-Paulik-Erdey derivatograph (the samples were heated in air from 20 to $1000^{\circ} \mathrm{C}$ at a rate of $10 \mathrm{~K} / \mathrm{min}$; the sample weight was $100 \mathrm{mg}$, a platinum crucible without a lid was used as the sample holder; and calcined alumina was used as the reference).

Selected crystallographic data and structure refinement data for $\mathbf{I}: \mathrm{C}_{8} \mathrm{H}_{24} \mathrm{~N}_{2} \mathrm{O}_{10} \mathrm{~S}, \mathrm{FW}=340.35$; trigonal system, space group $P-3, a=15.1249$ (12) $\AA, c=$ 7.6213(7) $\AA, V=1509.9(2) \AA^{3}$ at $T=293(2) \mathrm{K}, Z=4$, $\rho=1.497 \mathrm{~g} / \mathrm{cm}^{3} ; F_{000}=728$; a spherical crystal of diameter $0.3 \mathrm{~mm} ; \mu=0.266 \mathrm{~mm}^{-1}\left(\lambda\left(\operatorname{Mo} K_{\alpha}\right)=\right.$ $0.71073 \AA)$; transmission coefficient $T=0.925 ;-10 \leq$ $h \leq 16,-17 \leq k \leq 17,-9 \leq l \leq 8 ; \omega$-scan mode at $3^{\circ} \leq \theta \leq$ $26^{\circ}$; 3285 measured reflections; of these 1817 independent reflections $\left(R_{\text {int }}=0.039\right)$; and 458 observed reflections with $I_{h k l}>2 \sigma(I)$; coverage $91.7 \%$; fullmatrix refinement of 135 parameters on $F^{2}$; the final $R$-factors for the observed reflections: $R_{\mathrm{F}}=0.049$, $w R^{2}=0.166\left(R_{\mathrm{F}}=0.091, w R^{2}=0.191\right.$ for all independent reflections); $S=0.990 ; \Delta \rho_{\min } / \Delta \rho_{\max }=$ $-0.33 / 0.41 \mathrm{e} / \AA^{3}$. 


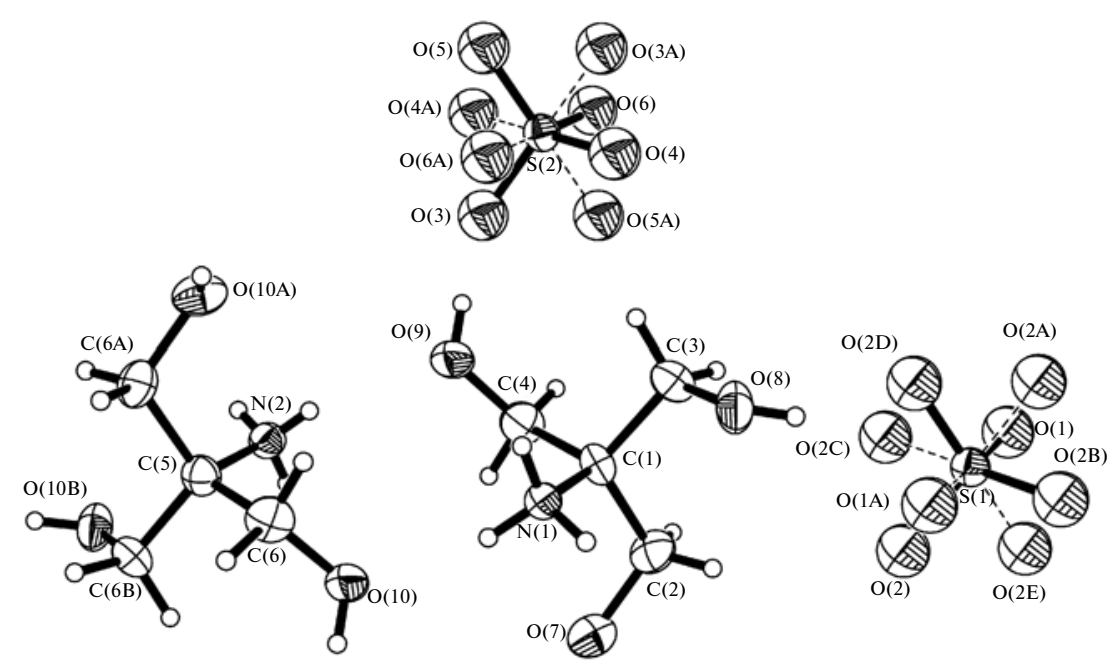

Fig. 1. Atom numbering and thermal vibration ellipsoids in structure I (probability level 50\%). Symmetrically equivalent atoms are designated by letters A to E. The bonds in the disordered components of sulfate ions are shown by dashed lines.

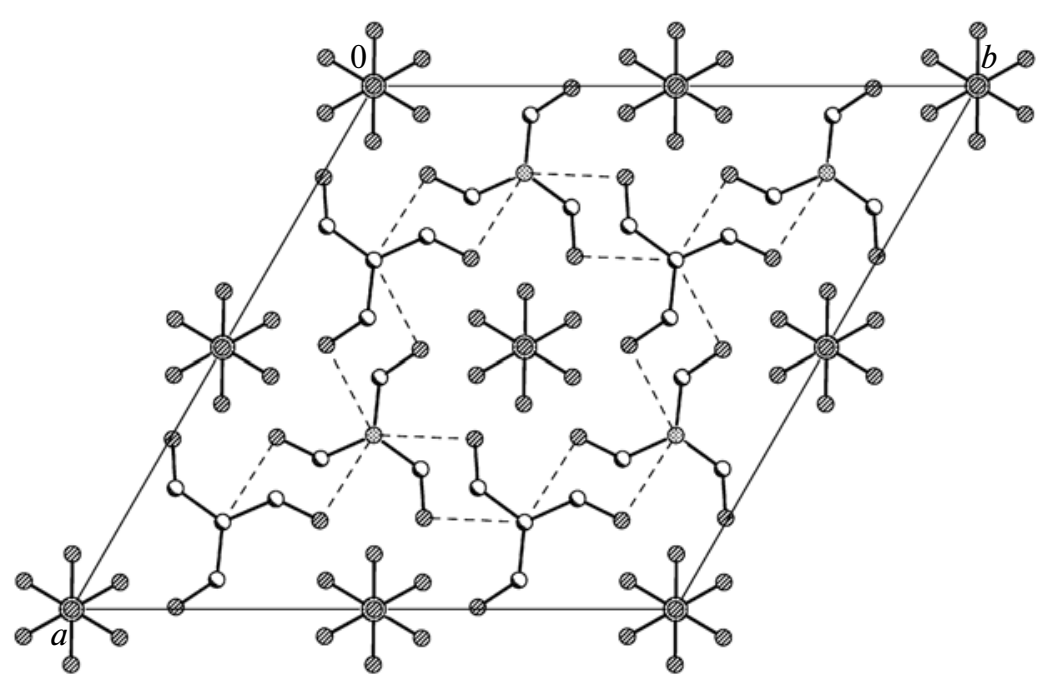

Fig. 2. Projection $x y 0$ of structure I (hydrogen atoms are omitted). Hydrogen bonds are shown by dashed lines.

\section{RESULTS AND DISCUSSION}

The composition of compound I was established from elemental analysis data.

For $\mathrm{C}_{6} \mathrm{H}_{22} \mathrm{~N}_{2} \mathrm{O}_{6} \mathrm{~S}$ anal. calcd. (\%): C, 28.23; N. 8.23; S, 9.24; H, 7.11.

Found (\%): C, 28.91; N, 8.45; S, 9.18; N, 7.25.

The atom coordinates, selected geometric characteristics, and hydrogen bond parameters of the structure are summarized in Tables 1, 2, and 3, respectively.

The mutual location of the structural units is shown in Fig. 1. The structure of $\mathbf{I}$ is peculiar as a general position of the independent part of the unit cell contains only one cation, namely, the $\mathrm{C}_{3} \mathrm{H}_{12} \mathrm{NO}_{3}^{+}$basis cation $(\mathrm{N}(1), \mathrm{C}(1)-\mathrm{C}(4)$, and $\mathrm{O}(7)-\mathrm{O}(9)$ atoms and hydrogen atoms connected to them in Fig. 1), the second cation occurs on a threefold axis, and both sulfate ions occur in special positions on threefold axes and in symmetry centers and, hence, they are disordered. As a result, the number of the compound formula units, $\left(\mathrm{C}_{3} \mathrm{H}_{12} \mathrm{NO}_{3}^{+}\right)_{2}\left(\mathrm{SO}_{4}^{2-}\right)$, is unusual for a trigonal cell $(Z=4)$. The location of sulfate ions (heavier scattering units) in special positions gives rise to a pseudoperiod $a^{\prime}=a / 2$, while the disorder of this ions leads to noticeable increase in the diffuse background of scattered X-radiation; as a result, the number of observed reflections with $I_{h k l}>2 \sigma(I)$ is relatively small irrespective of the exposure time.

The packing of structural units in the lattice is shown in Fig. 2. It can be seen that a three-dimensional hydrogen bond network (see also Table 3) is formed in the crystal only between the cations; the sulfate ions are not involved in these bonds, which is in line with the anion disorder in the structure. 
Table 1. Atom coordinates $\left(\times 10^{4}\right)$ and equivalent thermal factors $\left(\AA^{2} \times 10^{3}\right)$ in structure $\mathbf{I}$

\begin{tabular}{|c|c|c|c|c|}
\hline Atom & $x / a$ & $y / b$ & $z / c$ & $U_{\mathrm{eq}}$ \\
\hline$S(1)$ & 0 & 10000 & 0 & $28(1)$ \\
\hline$S(2)$ & 0 & 5000 & 0 & $28(1)$ \\
\hline $\mathrm{O}(1)$ & 0 & 10000 & $-1987(4)$ & $52(1)$ \\
\hline $\mathrm{O}(2)$ & $1059(1)$ & $10519(2)$ & $603(2)$ & $52(1)$ \\
\hline $\mathrm{O}(3)$ & $1059(2)$ & $5522(1)$ & $595(3)$ & $52(1)$ \\
\hline $\mathrm{O}(4)$ & $-516(1)$ & $5554(2)$ & $602(3)$ & $52(1)$ \\
\hline $\mathrm{O}(5)$ & $-550(1)$ & $3932(2)$ & $581(3)$ & $52(1)$ \\
\hline $\mathrm{O}(6)$ & $-3(1)$ & 4989(1) & $-2003(3)$ & $52(1)$ \\
\hline $\mathrm{O}(7)$ & $3257(1)$ & $9960(1)$ & $3362(1)$ & $36(1)$ \\
\hline $\mathrm{O}(8)$ & $45(1)$ & $8298(1)$ & $3360(1)$ & $38(1)$ \\
\hline $\mathrm{O}(9)$ & $1698(1)$ & $6742(1)$ & $3361(1)$ & $38(1)$ \\
\hline $\mathrm{O}(10)$ & $3293(1)$ & $8250(1)$ & $6641(1)$ & $37(1)$ \\
\hline $\mathrm{N}(1)$ & $1663(1)$ & $8332(1)$ & $5034(1)$ & $25(1)$ \\
\hline $\mathrm{N}(2)$ & 3333 & 6667 & $4977(2)$ & $26(1)$ \\
\hline$C(1)$ & $1670(1)$ & $8336(1)$ & $3074(2)$ & $27(1)$ \\
\hline$C(2)$ & $2318(1)$ & $9442(1)$ & $2442(2)$ & $35(1)$ \\
\hline$C(3)$ & $567(1)$ & $7882(1)$ & $2429(2)$ & $35(1)$ \\
\hline$C(4)$ & 2112(1) & $7676(1)$ & $2435(2)$ & $36(1)$ \\
\hline$C(5)$ & 3333 & 6667 & 6930(3) & $29(1)$ \\
\hline$C(6)$ & $2882(1)$ & $7320(1)$ & $7559(2)$ & $34(1)$ \\
\hline $\mathrm{H}(7)$ & 3731 & 10125 & 2674 & 55 \\
\hline $\mathrm{H}(8)$ & -77 & 8649 & 2695 & 57 \\
\hline $\mathrm{H}(9)$ & 1338 & 6269 & 2699 & 57 \\
\hline $\mathrm{H}(10)$ & 3633 & 8724 & 7313 & 56 \\
\hline $\mathrm{H}(1 \mathrm{~A})$ & 1553 & 8824 & 5422 & 37 \\
\hline $\mathrm{H}(1 \mathrm{~B})$ & 2263 & 8439 & 5429 & 37 \\
\hline $\mathrm{H}(1 \mathrm{C})$ & 1169 & 7730 & 5417 & 37 \\
\hline $\mathrm{H}(2)$ & 3748 & 7173 & 4649 & 40 \\
\hline $\mathrm{H}(2 \mathrm{~A})$ & 2453 & 9445 & 1197 & 42 \\
\hline $\mathrm{H}(2 \mathrm{~B})$ & 1941 & 9798 & 2613 & 42 \\
\hline $\mathrm{H}(3 \mathrm{~A})$ & 569 & 8023 & 1187 & 42 \\
\hline $\mathrm{H}(3 \mathrm{~B})$ & 209 & 7147 & 2583 & 42 \\
\hline $\mathrm{H}(4 \mathrm{~A})$ & 1969 & 7537 & 1194 & 43 \\
\hline $\mathrm{H}(4 \mathrm{~B})$ & 2847 & 8050 & 2585 & 43 \\
\hline $\mathrm{H}(6 \mathrm{~A})$ & 2147 & 6942 & 7400 & 41 \\
\hline $\mathrm{H}(6 \mathrm{~B})$ & 3019 & 7459 & 8802 & 41 \\
\hline
\end{tabular}


Table 2. Bond lengths and angles in structure $\mathbf{I}$

\begin{tabular}{|c|c|c|c|c|c|}
\hline Bond & $d, \AA$ & Bond & $d, \AA$ & Bond & $d, \AA$ \\
\hline $\mathrm{S}(1)-\mathrm{O}(1)$ & $1.514(3)$ & $\mathrm{O}(7)-\mathrm{C}(2)$ & $1.4171(15)$ & $\mathrm{N}(2)-\mathrm{C}(5)$ & $1.488(3)$ \\
\hline $\mathrm{S}(1)-\mathrm{O}(2)$ & $1.4611(18)$ & $\mathrm{O}(8)-\mathrm{C}(3)$ & $1.4204(16)$ & $C(1)-C(4)$ & $1.5312(19)$ \\
\hline $\mathrm{S}(2)-\mathrm{O}(3)$ & $1.4598(19)$ & $\mathrm{O}(9)-\mathrm{C}(4)$ & $1.4152(15)$ & $C(1)-C(3)$ & $1.5336(16)$ \\
\hline $\mathrm{S}(2)-\mathrm{O}(5)$ & $1.468(2)$ & $\mathrm{O}(10)-\mathrm{C}(6)$ & $1.4077(15)$ & $C(1)-C(2)$ & $1.5340(17)$ \\
\hline $\mathrm{S}(2)-\mathrm{O}(4)$ & $1.475(2)$ & $\mathrm{N}(1)-\mathrm{C}(1)$ & $1.4934(16)$ & $C(5)-C(6)$ & $1.5316(16)$ \\
\hline $\mathrm{S}(2)-\mathrm{O}(6)$ & \multicolumn{2}{|l|}{$1.527(2)$} & & & \\
\hline \multicolumn{2}{|l|}{ Angle } & $\omega$, deg & \multicolumn{2}{|l|}{ Angle } & $\omega$, deg \\
\hline \multicolumn{2}{|l|}{$\mathrm{O}(2) \# 1 \mathrm{~S}(1) \mathrm{O}(2)$} & $110.59(7)$ & \multicolumn{2}{|l|}{$\mathrm{C}(4) \mathrm{C}(1) \mathrm{C}(3)$} & 109.79(10) \\
\hline \multicolumn{2}{|l|}{$\mathrm{O}(2) \mathrm{S}(1) \mathrm{O}(1)$} & $108.33(7)$ & \multicolumn{2}{|l|}{$\mathrm{N}(1) \mathrm{C}(1) \mathrm{C}(2)$} & $108.52(10)$ \\
\hline \multicolumn{2}{|l|}{$\mathrm{O}(3) \mathrm{S}(2) \mathrm{O}(5)$} & $111.49(11)$ & \multicolumn{2}{|l|}{$\mathrm{C}(4) \mathrm{C}(1) \mathrm{C}(2)$} & $111.19(11)$ \\
\hline \multicolumn{2}{|l|}{$\mathrm{O}(3) \mathrm{S}(2) \mathrm{O}(4)$} & $110.25(11)$ & \multicolumn{2}{|l|}{$C(3) C(1) C(2)$} & $110.25(12)$ \\
\hline \multicolumn{2}{|l|}{$\mathrm{O}(5) \mathrm{S}(2) \mathrm{O}(4)$} & $111.20(11)$ & \multicolumn{2}{|l|}{$\mathrm{O}(7) \mathrm{C}(2) \mathrm{C}(1)$} & $111.40(11)$ \\
\hline \multicolumn{2}{|l|}{$\mathrm{O}(3) \mathrm{S}(2) \mathrm{O}(6)$} & $108.25(10)$ & \multicolumn{2}{|l|}{$\mathrm{O}(8) \mathrm{C}(3) \mathrm{C}(1)$} & $111.30(11)$ \\
\hline \multicolumn{2}{|l|}{$\mathrm{O}(5) \mathrm{S}(2) \mathrm{O}(6)$} & $107.00(10)$ & \multicolumn{2}{|l|}{$\mathrm{O}(9) \mathrm{C}(4) \mathrm{C}(1)$} & $111.89(11)$ \\
\hline \multicolumn{2}{|l|}{$\mathrm{O}(4) \mathrm{S}(2) \mathrm{O}(6)$} & $108.49(11)$ & \multicolumn{2}{|l|}{$\mathrm{N}(2) \mathrm{C}(5) \mathrm{C}(6)$} & $108.25(10)$ \\
\hline \multicolumn{2}{|l|}{$\mathrm{N}(1) \mathrm{C}(1) \mathrm{C}(4)$} & $108.66(11)$ & \multicolumn{2}{|l|}{$\mathrm{C}(6) \# 2 \mathrm{C}(5) \mathrm{C}(6)$} & 110.67(9) \\
\hline \multicolumn{2}{|l|}{$\mathrm{N}(1) \mathrm{C}(1) \mathrm{C}(3)$} & $108.36(10)$ & \multicolumn{2}{|l|}{$\mathrm{O}(10) \mathrm{C}(6) \mathrm{C}(5)$} & $111.87(11)$ \\
\hline
\end{tabular}

Symmetric codes for equivalent atoms: $\# 1-y+1, x-y+2, z ; \# 2-y+1, x-y+1, z$.

Table 3. Characteristics of hydrogen bonds D-H $\cdots$ A in structure I

\begin{tabular}{|c|c|c|c|c|c|}
\hline \multirow{2}{*}{$\mathrm{D}-\mathrm{H} \cdots \mathrm{A}$ contact } & \multicolumn{3}{|c|}{ Distance, $\AA$} & \multirow{2}{*}{ DHA angle, deg } & \multirow{2}{*}{ Coordinates of atom A } \\
\hline & $\mathrm{D}-\mathrm{H}$ & $\mathrm{H} \cdots \mathrm{A}$ & $\mathrm{D} \cdots \mathrm{A}$ & & \\
\hline $\mathrm{O}(7)-\mathrm{H}(7) \cdots \mathrm{O}(6)$ & 0.82 & 2.10 & $2.818(2)$ & 146.4 & $x-y+1, x+1,-z$ \\
\hline $\mathrm{O}(7)-\mathrm{H}(7) \cdots \mathrm{O}(4)$ & 0.82 & 2.75 & $3.378(2)$ & 135.0 & $x-y+1, x+1,-z$ \\
\hline $\mathrm{O}(7)-\mathrm{H}(7) \cdots \mathrm{O}(5)$ & 0.82 & 1.88 & $2.659(2)$ & 159.3 & $-x+y,-x+1, z$ \\
\hline $\mathrm{O}(8)-\mathrm{H}(8) \cdots \mathrm{O}(2)$ & 0.82 & 1.88 & $2.647(2)$ & 155.2 & $-x+y-1,-x+1, z$ \\
\hline $\mathrm{O}(8)-\mathrm{H}(8) \cdots \mathrm{O}(2)$ & 0.82 & 2.74 & $3.386(2)$ & 136.5 & $y-1,-x+y,-z$ \\
\hline $\mathrm{O}(9)-\mathrm{H}(9) \cdots \mathrm{O}(6)$ & 0.82 & 2.03 & 2.7895(19) & 153.1 & $-x,-y+1,-z$ \\
\hline $\mathrm{O}(9)-\mathrm{H}(9) \cdots \mathrm{O}(3)$ & 0.82 & 1.88 & $2.646(2)$ & 153.9 & \\
\hline $\mathrm{O}(9)-\mathrm{H}(9) \cdots \mathrm{O}(5)$ & 0.82 & 2.72 & $3.363(2)$ & 136.5 & $-x,-y+1,-z$ \\
\hline $\mathrm{O}(10)-\mathrm{H}(10) \cdots \mathrm{O}(6)$ & 0.82 & 2.07 & $2.810(2)$ & 150.8 & $-x+y,-x+1, z+1$ \\
\hline $\mathrm{O}(10)-\mathrm{H}(10) \cdots \mathrm{O}(3)$ & 0.82 & 2.74 & $3.384(2)$ & 136.4 & $-x+y,-x+1, z+1$ \\
\hline $\mathrm{O}(10)-\mathrm{H}(10) \cdots \mathrm{O}(4)$ & 0.82 & 1.88 & $2.651(2)$ & 156.4 & $x-y+1, x+1,-z+1$ \\
\hline $\mathrm{N}(1)-\mathrm{H}(1 \mathrm{~A}) \cdots \mathrm{O}(8)$ & 0.89 & 1.95 & $2.8103(13)$ & 161.0 & $x-y+1, x+1,-z+1$ \\
\hline $\mathrm{N}(1)-\mathrm{H}(1 \mathrm{~B}) \cdots \mathrm{O}(10)$ & 0.89 & 1.95 & $2.8100(14)$ & 161.6 & \\
\hline $\mathrm{N}(1)-\mathrm{H}(1 \mathrm{C}) \cdots \mathrm{O}(7)$ & 0.89 & 1.95 & $2.8028(13)$ & 161.3 & $y-1,-x+y,-z+1$ \\
\hline $\mathrm{N}(2)-\mathrm{H}(2) \cdots \mathrm{O}(9)$ & 0.75 & 2.09 & $2.8159(12)$ & 162.6 & $-x+y,-x+1, z$ \\
\hline
\end{tabular}


MS of $\left[\mathrm{M}_{\mathrm{TRIS}}-\mathrm{CH}_{2} \mathrm{OH}\right]^{+}(m / z=90, I=100 \%)$; $m / z=72, I=24 \% ; m / z=60, I=53 \% ; m / z=44, I=$ $18 \% ; m / z=42, I=43 \% ; m / z=30, I=40 \%$.

The results of analysis of the vibrational spectra of TRIS and compound $\mathbf{I}$ are presented in Table 4.

The following vibrations are active in the vibrational spectrum of the free $\mathrm{SO}_{4}^{2-}$ ion $\left(T_{d}\right.$ symmetry): $v_{1}\left(A_{1}\right.$, Raman), $983 \mathrm{~cm}^{-1}, v_{2}\left(E\right.$, Raman), $450 \mathrm{~cm}^{-1}$, $v_{3}\left(F_{2}\right.$, IR, Raman), $1105 \mathrm{~cm}^{-1}, v_{4}\left(F_{2}\right.$, IR, Raman $)$, $611 \mathrm{~cm}^{-1}[10]$.

According to X-ray diffraction data, the $\mathrm{SO}_{4}^{2-}$ ions in the crystal structure of $I$ are distorted corresponding to $C_{1}$ local symmetry (according to the arrangement of sulfate ions in the structure, the symmetry should be $C_{3 i}$ ), which changes the IR and Raman selection rules for the salt. In the region of $\mathrm{SO}_{4}^{2-}$ asymmetric stretching bands, the Raman spectrum of I was found to exhibit medium-intensity lines $\left(1129,1036 \mathrm{~cm}^{-1}\right)$ and an intense line $\left(1056 \mathrm{~cm}^{-1}\right)$, which are attributable to splitting components of the triply degenerate $v_{3}\left(F_{2}\right)$ vibration. In the IR spectrum, these are matched by a new medium-intensity band at $1131 \mathrm{~cm}^{-1}$ and a strong compound band at $\sim 1036 \mathrm{~cm}^{-1}$, which comprises apparently $v(\mathrm{CO})$ and $v(\mathrm{CN})$ vibrations.

Decrease in the symmetry of the $\mathrm{SO}_{4}^{2-}$ ion is accompanied by appearance of a fully symmetric $v_{1}$ $\left(A_{1}\right)$ stretching band at $990 \mathrm{~cm}^{-1}$ in the IR spectrum of $\mathbf{I}$. In the Raman spectrum, this vibration gives rise to the $978 \mathrm{~cm}^{-1}$ band.

The three components of the $v_{4}$ asymmetric bending vibration of the $\mathrm{SO}_{4}^{2-}$ ion occur in the IR spectrum of $I$ as a fairly intense doublet with peaks at 618 and $598 \mathrm{~cm}^{-1}$ and a clearly resolved shoulder at $578 \mathrm{~cm}^{-1}$. These bands are easily interpreted upon comparison of the IR spectra of I and TRIS. In the Raman spectrum, these vibrations are responsible for two mediumintensity lines at 607 and $580 \mathrm{~cm}^{-1}$.

The $526-423 \mathrm{~cm}^{-1}$ range of the IR spectrum of $\mathbf{I}$, which typically exhibits $\mathrm{SO}_{4}^{2-}$ symmetric bending vibrations and the out-of-plane bending vibrations of the cation, contains four low-intensity bands (Table 4), whereas in the Raman spectrum, only two weak bands were detected at 456 and $411 \mathrm{~cm}^{-1}$. Hence, the IR bands at 490 and $423 \mathrm{~cm}^{-1}$ can be assigned to the split components of $\mathrm{v}_{2}(E)$, while the bands at 526 and $514 \mathrm{~cm}^{-1}$ can be assigned to skeletal modes of the cation, which are not usually manifested in the Raman spectra.

Among the natural vibrations of the cation manifested in the IR spectrum of $\mathbf{I}$, note the broad band $v(\mathrm{OH})$ with a peak at $\sim 3400 \mathrm{~cm}^{-1}$, which shifts to higher frequency on going from the spectrum of TRIS to the spectrum of I due to redistribution of the
Table 4. Wave numbers $\left(\mathrm{cm}^{-1}\right)$ of the IR and Raman absorption peaks in the spectra of TRIS and I

\begin{tabular}{|c|c|c|c|}
\hline TRIS & \multirow{2}{*}{ Assignment* } & \multicolumn{2}{|c|}{$(\mathrm{TRISH})_{2} \mathrm{SO}_{4}(\mathrm{I})$} \\
\hline IR & & IR & Raman \\
\hline $\begin{array}{l}3370 \mathrm{~s} \\
3330 \mathrm{sh} \\
3300 \mathrm{~s} \\
3200 \mathrm{~m} . \mathrm{br}\end{array}$ & $\begin{array}{l}v(\mathrm{OH}), v_{\mathrm{as}, \mathrm{s}}\left(\mathrm{NH}_{2}\right), \\
v\left(\mathrm{NH}_{3}^{+}\right)\end{array}$ & $\begin{array}{l}3400 \mathrm{~s} . \mathrm{br} \\
3290 \mathrm{sh} \\
3230 \mathrm{~s} . \mathrm{br} \\
3000 \mathrm{~s}\end{array}$ & $3096 \mathrm{~m}$ \\
\hline 2670 m.br & $v\left(\mathrm{NH}_{3}^{+}\right)$ & $\begin{array}{l}2705 \mathrm{sh} \\
2600 \mathrm{sh} \\
2365 \mathrm{~m}\end{array}$ & $2771 \mathrm{~m}$ \\
\hline $1600 \mathrm{~s}$ & $\begin{array}{l}\delta_{\mathrm{as}, \mathrm{s}}\left(\mathrm{NH}_{2}\right) \\
\delta_{\mathrm{as,s}}\left(\mathrm{NH}_{3}^{+}\right)\end{array}$ & $\begin{array}{l}1632 \mathrm{~s} \\
1552 \mathrm{~s}\end{array}$ & $1648 \mathrm{w}$ \\
\hline $\begin{array}{l}1500 \mathrm{sh} \\
1400 \mathrm{w}\end{array}$ & $\delta(\mathrm{CNH})$ & & \\
\hline $\begin{array}{l}1340 \mathrm{~m} \\
1310 \mathrm{~m} \\
1295 \mathrm{~m} \\
1260 \mathrm{w}\end{array}$ & $\begin{array}{l}\delta(\mathrm{COH}), \tau\left(\mathrm{CH}_{2}\right), \\
\rho\left(\mathrm{NH}_{3}^{+}\right), v(\mathrm{CC})\end{array}$ & $\begin{array}{l}1343 \mathrm{w} \\
1295 \mathrm{~m} \\
1245 \mathrm{w} \\
\end{array}$ & $1306 \mathrm{~m}$ \\
\hline $1215 \mathrm{~m}$ & $\omega\left(\mathrm{NH}_{2}\right), \omega\left(\mathrm{NH}_{3}^{+}\right)$ & $1195 \mathrm{sh}$ & $1206 \mathrm{~m}$ \\
\hline $1175 \mathrm{~m}$ & $\omega\left(\mathrm{CH}_{2}\right)$ & $1150 \mathrm{~m}$ & $1154 \mathrm{w}$ \\
\hline $\begin{array}{l}1090 \mathrm{~m} \\
1075 \mathrm{~m} \\
1040 \mathrm{~s}\end{array}$ & $\begin{array}{l}v(\mathrm{CO}), v(\mathrm{CN}), \\
v_{3}\left(\mathrm{SO}_{4}\right)\end{array}$ & $\begin{array}{l}1131 \mathrm{~m} \\
1065 \mathrm{~s} \\
1036 \mathrm{~s}\end{array}$ & $\begin{array}{l}1129 \mathrm{~m} \\
1066 \mathrm{~m} \\
1056 \mathrm{~s} \\
1036 \mathrm{~m}\end{array}$ \\
\hline $1020 \mathrm{~m}$ & $v(\mathrm{CC})$ & & \\
\hline & $v_{1}\left(\mathrm{SO}_{4}\right)$ & $990 \mathrm{~m}$ & $978 \mathrm{~m}$ \\
\hline $\begin{array}{l}960 \mathrm{~m} \\
915 \mathrm{w} \\
890 \mathrm{~m} \\
805 \mathrm{~m} \\
\end{array}$ & $\begin{array}{l}\rho\left(\mathrm{NH}_{2}\right), \rho\left(\mathrm{NH}_{3}^{+}\right), \\
\rho\left(\mathrm{CH}_{2}\right),\end{array}$ & $\begin{array}{l}944 \mathrm{~s} \\
915 \mathrm{~m} \\
870 \mathrm{~m}\end{array}$ & $\begin{array}{l}965 \mathrm{~s} \\
925 \mathrm{~m} \\
914 \mathrm{~m}\end{array}$ \\
\hline $\begin{array}{l}785 \mathrm{~m} \\
630 \mathrm{~m}\end{array}$ & $\begin{array}{l}\delta(\mathrm{COH}), \delta(\mathrm{CCC}) \\
\tau(\mathrm{CO})\end{array}$ & $\begin{array}{l}787 w \\
686 w \\
676 w\end{array}$ & $\begin{array}{l}765 \mathrm{~s} \\
696 \mathrm{~m}\end{array}$ \\
\hline & $v_{4}\left(\mathrm{SO}_{4}\right)$ & $\begin{array}{l}618 \mathrm{~m} \\
598 \mathrm{~m} \\
578 \mathrm{sh}\end{array}$ & $\begin{array}{l}607 \mathrm{~m} \\
580 \mathrm{~m}\end{array}$ \\
\hline $\begin{array}{l}520 \mathrm{w} \\
470 \mathrm{w} \\
445 \mathrm{w}\end{array}$ & $\begin{array}{l}\delta(\mathrm{NCC}), \delta(\mathrm{CCO}) \\
v_{2}\left(\mathrm{SO}_{4}\right)\end{array}$ & $\begin{array}{l}526 \mathrm{w} \\
514 \mathrm{w} \\
490 \mathrm{w} \\
\\
423 \mathrm{w}\end{array}$ & $\begin{array}{l}456 \mathrm{w} \\
411 \mathrm{w}\end{array}$ \\
\hline
\end{tabular}

* Bending vibrations: $\delta$ is scissor; $\omega$ is wagging; $\tau$ is torsional, $\rho$ is rocking vibration.

$\mathrm{H}$-bond system. The $3290-2365 \mathrm{~cm}^{-1}$ range displays broad structured stretching bands for the $\mathrm{NH}_{3}^{+}$ions involved in the $\mathrm{H}$-bonding. The $\delta_{\text {as, }}\left(\mathrm{NH}_{3}^{+}\right)$modes occur as two relatively strong bands at 1632 and $1552 \mathrm{~cm}^{-1}$. In 
the Raman spectrum, vibrations of $v\left(\mathrm{NH}_{3}^{+}\right)$are responsible for medium-intensity bands at 3096 and $2771 \mathrm{~cm}^{-1}$; the $\delta\left(\mathrm{NH}_{3}^{+}\right)$modes having low activity in the Raman spectra give rise to a weak band at $1648 \mathrm{~cm}^{-1}$.

According to thermogravimetry data, thermolysis of compound $\mathbf{I}$ is accompanied by melting of the salt (endotherm at $130-155^{\circ} \mathrm{C}$ without mass loss) followed by elimination to the gas phase of 1 mole of $\mathrm{H}_{2} \mathrm{SO}_{4}$ (products of its decomposition; endotherm at $225-260^{\circ} \mathrm{C}, \Delta m_{\text {exp }}=27.5 \%, \Delta m_{\text {calcd }}=28.8 \%$ ) [11] and TRIS destruction products (endotherm at $T_{\max }=$ $285^{\circ} \mathrm{C}$ ). Attention is attracted by the obvious analogy of the thermochemical behaviors of salts $\mathbf{I}$ and (TRISH) ${ }_{2} \mathrm{SiF}_{6}$ [6]: the hexafluorosilicate melts (endotherm at $145-161{ }^{\circ} \mathrm{C}$ ) and decomposes to give off 1 mole of $\mathrm{SiF}_{4}$ and 2 moles of KF (endotherm at 200$268^{\circ} \mathrm{C}$ ) to the gas phase. The heats observed at higher temperature are related to boiling and decomposition of TRIS. This fact is in line with the similarity of acid characteristics of sulfuric and hexafluorosilicic acids and, as a consequence, almost equal thermal stabilities of the corresponding onium salts.

In conclusion we would like no note that ethanolamines, which structurally resemble TRIS, react with sulfur(IV) oxide under similar conditions to give hydrogen sulfite (or sulfite) onium salts [12, 13]. Evidently, elucidation of the relationship between the structure of the organic base $\mathrm{L}$ and the composition of the onium product formed in the $\mathrm{SO}_{2}-\mathrm{L}-\mathrm{H}_{2} \mathrm{O}$ system and contacting with air oxygen (sulfite, hydrogen sulfite or sulfate form) requires further research using a broad range of bases of various structural classes.

\section{REFERENCES}

1. T. Nakamura, T. Nagasawa, F. Yu, et al., Appl. Environ. Microbiol. 60, 4630 (1994).

2. F. Danel, M. Paetzel, N. C. J. Strynadka, and M. G. P. Page, Biochemistry 40, 9412 (2001).

3. R. Kisilevsky, W. Szarek, and D. Weaver, US Patent 5972328, 26.10.1999.

4. J. Li. Tamarit, M. A. Perez-Jubindo, and M. A. de la Fuente, J. Phys.: Condens. Matter 9, 5469 (1997).

5. M. T. Averbuch-Pouchot, C. R. Acad. Sci. Paris 318, 191 (1994).

6. V. O. Gel'mbol'dt, L. A. Gavrilova, G. P. Sokhranenko, and A. A. Ennan, Russ. J. Inorg. Chem. 48, 1431 (2003).

7. B. Kosturek, Z. Czapla, and A. Waśkowska, Z. Naturforsc. A 58, 121 (2003).

8. V. A. Klimova, Basic Organic Analysis Methods (Khimiya, Moscow, 1975) [in Russian].

9. G. M. Sheldrick, Acta Crystallogr. Sect. A 64, 112 (2008).

10. K. Nakamoto, K. Infrared and Raman Spectra of Inorganic and Coordination Compounds (Interscience, New York, 1986; Mir, Moscow, 1991).

11. Handbook of Acid Productionh Engineer, Ed. by K. M. Mamin (Khimiya, Moscow, 1971), p. 85 [in Russian].

12. R. E. Khoma, V. O. Gel'mbol'dt, L. V. Koroeva, et al., Vopr. Khim. Khim. Tekhnol., No. 1, 133 (2012).

13. R. E. Khoma, A. A. Ennan, A. V. Mazepa, and V. O. Gel'mbol'dt, Vopr. Khim. Khim. Tekhnol., No. 1, 136 (2013).

Translated by Z. Svitanko 